\title{
Komparasi Keefektifan Pendekatan CTL Setting NHT dan TGT pada Materi Bangun Datar
}

\author{
Andriani Suzana \\ Universitas Nahdlatul Ulama Ghozali Cilacap. Jl. Kemerdekaan Barat No.17, Kesugihan Kidul, \\ Kesugihan, Kabupaten Cilacap, Jawa Tengah 53274, Indonesia \\ Email: math_andriani@yahoo.co.id
}

Received: 25January 2017; Revised:10 April 2017; Accepted: 5 May 2017

\begin{abstract}
Abstrak
Tujuan penelitian ini adalah untuk mendeskripsikan keefektifan pendekatan CTL setting NHT dan TGT dan membandingkan keefektifan pendekatan CTL setting NHT dan pendekatan CTL setting TGT ditinjau dari prestasi belajar, kemampuan komunikasi matematis, dan sikap matematika siswa SMP kelas VII dalam belajar bangun datar. Penelitian ini merupakan penelitian eksperimen semu dengan desain pretest-posttest non-equivalent comparison-group design. Untuk mengetahui keefektifan pendekatan CTL setting NHT dan TGT pada masing-masing variabel, digunakan uji one sample t-test. Selanjutnya, untuk membandingkan keefektifan pendekatan CTL setting NHT dan TGT, data dianalisis menggunakan uji $\mathrm{T}^{2}$ Hotteling's. Jika terdapat perbedaan keefektifan, maka dilakukan uji lanjut t-univariat. Hasil penelitian menunjukkan bahwa pembelajaran matematika menggunakan pendekatan CTL setting NHT dan TGT efektif ditinjau dari prestasi belajar dan sikap matematika siswa, namun tidak efektif ditinjau dari kemampuan komunikasi matematis dan tidak terdapat perbedaan keefektifan antara pembelajaran menggunakan pendekatan CTL setting NHT dan pembelajaran menggunakan pendekatan CTL setting TGT ditinjau dari prestasi belajar, kemampuan komunikasi matematis, dan sikap matematika siswa.
\end{abstract}

Kata Kunci: pendekatan CTL setting NHT, pendekatan CTL setting TGT, prestasi belajar, kemampuan komunikasi matematis, sikap matematika siswa

\section{The Comparison of the Effectiveness of CTL Approach of NHT Type and CTL Approach of TGT Type in Learning Planes}

\begin{abstract}
This research aims to describe the effectiveness of teaching mathematics by using the CTL approach of NHT type and the CTL approach of TGT type; compare the effectiveness of the CTL approach of NHT type and CTL approach of TGT type in terms of mathematics learning achievement, mathematical communication ability, and mathematics attitude of 7th grade junior high school students in learning planes. This research is a quasi-experimental research with the pretest-posttest non-equivalent comparison-group design. To determine the effectiveness of the CTL approach of NHT type and CTL approach of TGT type on each variable, one sample t-test was used. Furthermore, to compare the effectiveness of the CTL approach of NHT type and CTL approach of TGT type, the data were analyzed using a multivariate test of $T^{2}$ Hotteling's. If there were differences in effectiveness, then further study of $t$ univariate was done to determine certain variables that contributed to the overall difference. The results showed that: the teaching of mathematics using the CTL approach of NHT type and using the CTL approach of TGT type are effective in terms of mathematics learning achievement and mathematics attitude, but is not effective in terms of mathematical communication ability; there is no difference between the effectiveness of teaching using the CTL approach of NHT type and teaching using the CTL approach of TGT type in terms of mathematics learning achievement, mathematical communication ability, and mathematics attitude.
\end{abstract}

Keywords: CTL approach of NHT type, CTL approach of TGT type, mathematics learning achievement, mathematical communication ability, mathematics attitudes of students

How to Cite: Suzana, A. (2017). Komparasi keefektifan pendekatan CTL setting NHT dan TGT pada materi bangun datar. Jurnal Riset Pendidikan Matematika, 4(1), 21-31. doi:http://dx.doi.org/10.21831/jrpm.v4i1.12727

Permalink/DOI: http://dx.doi.org/10.21831/jrpm.v4i1.12727 


\section{Jurnal Riset Pendidikan Matematika, 4 (1), 2017 - 22}

Andriani Suzana

\section{PENDAHULUAN}

Matematika merupakan ilmu yang memegang peranan penting dalam berbagai bidang kehidupan. Salah satunya dalam kemajuan ilmu pengetahuan dan teknologi. National Council of Teachers of Mathematics menyatakan bahwa: "mathematical competence opens doors to productive futures. A lack of mathematical competence keeps those doors closed" (The National Council of Teachers of Mathematics, 2000, p. 5). Hal ini menunjukkan bahwa sampai batas tertentu matematika perlu dikuasai oleh setiap warga, baik penerapan maupun pola pikirnya. Dengan demikian, peranan pendidikan matematika sangat penting dalam usaha mengembangkan sumber daya manusia yang bermutu tinggi. Sumber daya manusia yang bermutu tinggi salah satunya diperoleh melalui kegiatan pembelajaran di sekolah yang berkualitas.

Berkaitan dengan hal itu, Lampiran III Peraturan Menteri Pendidikan dan Kebudayaan Nomor 58 tahun 2014 tentang Kurikulum SMP menyatakan bahwa kegiatan pembelajaran pada setiap satuan pendidikan (sekolah) harus diarahkan untuk memberdayakan semua potensi yang dimiliki peserta didik agar mereka dapat memiliki kompetensi yang diharapkan melalui upaya menumbuhkan serta mengembangkan sikap (attitude), pengetahuan (knowledge), dan keterampilan (skill). Sesuai dengan Standar Kompetensi Lulusan (SKL) dan Standar Isi Kurikulum 2013, maka prinsip pembelajaran yang digunakan adalah dimulai dengan peserta didik diberi tahu menuju peserta didik mencari tahu (Menteri Pendidikan dan Kebudayaan Republik Indonesia, 2014, p. 337). Selama ini semua pendidik dan pengambil keputusan dalam bidang pendidikan selalu menganggap siswa sebagai Empty Vessel yaitu sebagai tong kosong yang harus diisi oleh guru (Marsigit, 2013b, p. 4).

Programme for International Student Assesssment (PISA) tahun 2009 telah melakukan penilaian tentang kemampuan siswa dalam matematika. Hasil penelitian secara rinci menunjukkan bahwa sebagian besar siswa peserta dari Indonesia masih kesulitan, bahkan ketika mereka memilih dan menerapkan sebuah strategi yang tepat untuk memecahkan sebuah permasalahan sederhana (OECD, 2010, p. 221). Ini menunjukkan bahwa kemampuan matematika siswa Indonesia masih berada pada level yang rendah.
Berdasarkan hasil survei yang dilakukan melalui wawancara dengan guru matematika SMP Negeri 8 Yogyakarta, prestasi belajar matematika siswa materi bangun datar di SMP Negeri 8 Yogyakarta sudah cukup bagus. Meskipun begitu, guru matematika di SMP Negeri 8 Yogyakarta belum pernah menerapkan pembelajaran matematika dengan menggunakan pendekatan CTL setting NHT dan pendekatan CTL setting TGT. Hal inilah yang ingin peneliti kaji, apakah dengan menerapkan pembelajaran seperti ini prestasi belajar matematika siswa materi bangun datar akan semakin baik atau justru malah sebaliknya. Selain itu, dari hasil ujian nasional menunjukkan bahwa rata-rata daya serap siswa SMP Negeri 8 Yogyakarta terhadap materi bangun datar mengalami penurunan untuk dua kemampuan yang diujikan, dilihat dari tahun 2010/2011, 2011/2012, dan 2012/ 2013 sebagai-mana ditunjukkan pada Tabel 1.

Tabel 1. Persentase Penguasaan Materi UN

\begin{tabular}{|c|c|c|}
\hline Tahun & Kemampuan yang Diuji & $\begin{array}{l}\text { Daya } \\
\text { Serap }\end{array}$ \\
\hline $2010 / 2011$ & $\begin{array}{l}\text { Menyelesaikan masalah } \\
\text { yang berkaitan dengan luas } \\
\text { gabungan dua bangun datar }\end{array}$ & 95,06 \\
\hline \multirow[b]{2}{*}{$2011 / 2012$} & $\begin{array}{l}\text { Menyelesaikan masalah } \\
\text { yang berkaitan dengan luas } \\
\text { bangun datar }\end{array}$ & 78,98 \\
\hline & $\begin{array}{l}\text { Menyelesaikan masalah } \\
\text { yang berkaitan dengan } \\
\text { garis-garis istimewa pada } \\
\text { segitiga }\end{array}$ & 92,68 \\
\hline $2012 / 2013$ & $\begin{array}{l}\text { Menyelesaikan masalah } \\
\text { yang berkaitan dengan } \\
\text { garis-garis istimewa pada } \\
\text { segitiga }\end{array}$ & 81,17 \\
\hline
\end{tabular}

Sumber: (Depdiknas, 2011, 2012, 2013): Laporan

Hasil UN Tahun 2010/2011, 2011/2012, 2012/2013

Selain prestasi belajar, hal lain yang perlu diperhatikan adalah kemampuan komunikasi matematis. Seringkali guru menjelaskan suatu materi dengan menggunakan bahasa yang kurang bisa dipahami oleh siswa, sehingga gagasan dari materi tidak tersampaikan dengan. Akibatnya sebagian besar siswa beranggapan bahwa matematika merupakan pelajaran yang sulit dipahami. Padahal ketika siswa ditantang untuk mengomunikasikan penalaran mereka baik secara lisan maupun tulisan, siswa akan lebih menikmati matematika dan berpikir bahwa matematika merupakan sesuatu yang menyenangkan (Hirschfeld-Cotton, 2008, p. 1).

Berdasarkan hasil pretest kemampuan komunikasi matematis siswa yang dilakukan 
pada tanggal 9 dan 10 Februari 2015, tampak bahwa rata-rata nilai pretest kemampuan komunikasi siswa materi bangun datar di SMP Negeri 8 Yogyakarta adalah sebesar 20,65 dan 27,14 dari skala 100. Rendahnya nilai pretest kemampuan komunikasi matematis siswa bukan karena mereka tidak bisa mengerjakan soal, akan tetapi mereka belum dapat mengerjakan soal sesuai dengan langkah-langkah kemampuan komunikasi yang lengkap, jelas, dan tepat. Nilai pretest yang masih jauh dari Kriteria Ketuntasan Minimal (KKM) merupakan suatu permasalahan serius. Hal ini karena kemampuan komunikasi matematika merupakan hal yang penting dalam pembelajaran matematika di sekolah.

Terlebih lagi dalam Permendikbud Nomor 58 Tahun 2014 tentang Kurikulum SMP, pada lampirannya menegaskan bahwa salah satu tujuan pembelajaran matematika SMP adalah agar peserta didik memiliki kemampuan untuk mengomunikasikan gagasan dan penalaran matematika dengan jelas, baik secara lisan maupun tulisan. Memperhatikan Peraturan Menteri Pendidikan dan Kebudayaan tersebut, maka kemampuan komunikasi matematis merupakan faktor yang sangat penting dalam pembelajaran. Hal ini dipertegas dalam (The National Council of Teachers of Mathematics, 2000, p. 60) bahwa: "communication is an essential part of mathematics and mathematics education". Ini memberikan makna bahwa komunikasi adalah bagian yang terpenting dari matematika dan pendidikan matematika.

Sesuai dengan tujuan Kurikulum 2013, maka sudah sepatutnya proses pembelajaran matematika tidak hanya fokus pada pengetahuan kognitif saja, namun pada pengembangan pengetahuan afektif seperti sikap matematika siswa. Hal ini penting mengingat sikap positif terhadap matematika akan berkorelasi positif dengan prestasi belajar matematika. Apalagi proses pembelajaran sesuai dengan Kurikulum 2013 harus menyentuh tiga ranah kompetensi, yaitu sikap, pengetahuan, dan keterampilan.

Melihat rendahnya prestasi belajar di SMP Negeri 8 Yogyakarta, maka sikap yang mempunyai korelasi dengan prestasi tersebut patut untuk diperhatikan. Sikap merupakan suatu komponen yang sangat mempengaruhi keberhasilan program pembelajaran. Siswa yang memiliki sikap positif akan menunjukkan tindakan yang selalu mengarah pada upaya pencapaian tujuan pembelajaran matematika. Salah satu hal yang perlu diperhatikan seorang guru dalam menyukseskan pembelajarannya adalah menciptakan suatu kondisi dan iklim pembelajaran yang bisa merangsang dan meningkatkan sikap positif siswa dalam pembelajaran matematika. Namun, fakta menunjukan bahwa sikap matematika sebagai salah satu komponen kunci berpikir matematika belum banyak mendapat perhatian guru di sekolah.

Berdasarkan kondisi tersebut, maka sudah seharusnya pembelajaran matematika dilakukan untuk mengkonstruksi pengetahuan siswa. Teori belajar yang dilandasi oleh filsafat konstruktivisme menyatakan bahwa pengetahuan tidak dapat dipindahkan dari yang mengetahui kepada siswa. Pengetahuan yang dimiliki seseorang adalah konstruksi atau bentukan dari orang itu sendiri. Oleh karena itu, guru dituntut untuk menerapkan berbagai pendekatan pembelajaran yang sesuai dengan kekhasan materi dan karakteristik siswa, sehingga guru dapat memfasilitasi aktivitas siswa dalam belajar. Sejalan dengan tuntutan tersebut, maka diperlukan inovasi atau perubahan dalam berbagai komponen pendidikan, seperti pendekatan pembelajaran. Salah satu pendekatan pembelajaran yang sesuai dengan permasalahan tersebut dan cocok dengan Kurikulum 2013 (SMP) adalah pendekatan kontekstual (Marsigit, 2013a, p. 1).

Pembelajaran dengan pendekatan kontekstual merupakan suatu proses pembelajaran yang membantu guru mengaitkan materi pembelajaran dengan situasi dunia nyata siswa dan memotivasi siswa untuk membuat hubungan antara pengetahuan yang dimiliki dengan aplikasinya dalam kehidupan sehari-hari. Menurut Widdiharto (2004, p. 19), pembelajaran dengan pendekatan kontekstual setting model pembelajaran kooperatif dapat melibatkan siswa aktif dalam proses belajar mengajar melalui diskusi kelompok. Dengan ini siswa akan lebih mudah memahami materi, menemukan banyak hal yang menarik dalam mempelajari matematika, dan mengaitkan materi yang diajarkan dengan kehidupan sehari-hari.

Pembelajaran kooperatif merupakan model pembelajaran yang efektif untuk meningkatkan prestasi belajar, kemampuan komunikasi matematis, dan sikap matematika siswa. Menurut Slavin (2014, p. 262) untuk meningkatkan prestasi belajar, model pembelajaran kooperatif mempunyai efek yang positif dengan cara memanfaatkan interaksi dalam kelompok. Hal yang sama dikemukakan Kose, Sahin, Ergun, \& Gezer (2010, p. 170) bahwa "cooperative learning is effective in developing students upper level mental abilities, communicative skills, 
achievement, retension, recall, transfer, motivation and attitude". Artinya, pembelajaran kooperatif efektif dalam mengembangkan prestasi belajar, kemampuan komunikasi matematis, dan sikap matematika siswa.

Adapun model pembelajaran kooperatif yang dimaksudkan dalam penelitian ini adalah model pembelajaran kooperatif tipe NHT dan TGT. Pembelajaran kooperatif tipe NHT dan TGT dapat memotivasi siswa untuk saling mendukung dan membantu satu sama lain dalam menguasai kemampuan yang diajarkan guru. Mereka harus mendukung teman satu timnya untuk dapat melakukan yang terbaik, menunjukkan norma bahwa belajar itu penting, berharga, dan menyenangkan (Slavin, 2005, p. 13). Keadaan yang seperti ini dapat meningkatkan kemampuan siswa untuk bersosialisasi dengan teman dan guru sehingga dapat meningkatkan prestasi belajar, kemampuan komunikasi matematis, dan sikap matematika siswa.

Melihat hal tersebut, peneliti merasa persoalan ini penting untuk diperhatikan. Peneliti termotivasi untuk mencari solusi yang mampu meningkatkan prestasi belajar matematika siswa khususnya pada materi bangun datar. Dengan menerapkan pembelajaran menggunakan pendekatan kontekstual setting NHT dan TGT diharapkan dapat meningkatkan prestasi belajar siswa materi bangun datar, meningkatkan kemampuan komunikasi matematis dan sikap matematika siswa. Oleh karena itu peneliti tertarik untuk melaksanakan penelitian dengan judul "Komparasi Keefektifan Pendekatan CTL Setting NHT dan TGT Pada Materi Bangun Datar".

Agar penelitian ini lebih terarah, maka penelitian ini difokuskan pada prestasi belajar geometri, terutama pada materi bangun datar di SMP Negeri 8 Yogyakarta yang mengalami penurunan untuk dua kemampuan yang diujikan pada Ujian Nasional, kemampuan komunikasi matematika siswa SMP Negeri 8 Yogyakarta yang masih kurang, dan sikap matematika sebagai salah satu komponen kunci berpikir matematika belum banyak mendapat perhatian guru di sekolah.

Adapun tujuan yang ingin dicapai dalam penelitian ini adalah mendeskripsikan keefektifan pendekatan CTL setting NHT dan pendekatan CTL setting TGT jika ditinjau dari prestasi belajar, kemampuan komunikasi matematis, dan sikap matematika siswa SMP kelas VII dalam belajar bangun datar dan membandingkan keefektifan pendekatan CTL setting NHT dan pendekatan CTL setting TGT ditinjau dari prestasi belajar, kemampuan komunikasi matematis, dan sikap matematika siswa SMP kelas VII dalam belajar bangun datar.

\section{METODE}

Jenis penelitian ini adalah penelitian kuantitatif dengan metode eksperimen semu (quasi eksperiment) karena tidak semua variabel yang muncul dan kondisi eksperimen dapat diatur serta dikontrol secara ketat. Dalam penelitian ini, tidak semua variabel dapat dikontrol mengingat prestasi belajar, kemampuan komunikasi matematis dan sikap matematika siswa dapat dipengaruhi oleh banyak faktor, seperti pengaruh dari lingkungan keluarga, lingkungan sekolah, dan lingkungan masyarakat.

Penelitian ini dilaksanakan di SMP Negeri 8 Yogyakarta. Penelitian ini telah dilaksanakan pada semester genap tahun pelajaran 2014/2015 yang dimulai dari tanggal 9 Februari 2015 sampai 10 Maret 2015. Penelitian dilaksana-kan berdasarkan jadwal pembelajaran semester genap di sekolah tersebut. Deskripsi pelaksanaan penelitian disajikan dalam Tabel 2.

Tabel 2. Deskripsi Pelaksanaan Penelitian

\begin{tabular}{ccc}
\hline Tanggal & Jam Pelajaran & Kelas \\
\hline 9 Februari 2015 & $10.30-12.30$ & VII 1 \\
10 Februari 2015 & $07.15-09.15$ & VII 2 \\
14 Februari 2015 & $07.15-08.35$ & VII 1 \\
16 Februari 2015 & $10.50-12.10$ & VII 2 \\
17 Februari 2015 & $07.30-12.30$ & VII 1 \\
21 Februari 2015 & $07.15-08.35$ & VII 2 \\
23 Februari 2015 & $10.50-12.10$ & VII 2 \\
24 Februari 2015 & $0.30-12.30$ & VII 1 \\
28 Februari 2015 & $07.15-09.15$ & VII 2 \\
2 Maret 2015 & $10.50-12.10$ & VII 1 \\
3 Maret 2015 & $07.30-12.30$ & VII 1 \\
7 Maret 2015 & $07.15-09.15$ & VII 2 \\
9 Maret 2015 & $10.50-12.10$ & VII 1 \\
10 Maret 2015 & $07.30-12.30$ & VII 1 \\
\hline
\end{tabular}

Populasi dari penelitian ini adalah seluruh siswa kelas VII SMP Negeri 8 Yogyakarta yang terbagi menjadi sepuluh kelas tahun ajaran 2014/2015. Sampel dalam penelitian ini adalah dua kelas yang dipilih dengan menggunakan teknik random sampling. Dari hasil pengundian diperoleh hasil bahwa sampel dalam penelitian ini adalah siswa kelas VII 1 dan siswa kelas VII 2 SMP Negeri 8 Yogyakarta yang masingmasing berjumlah 34 siswa. Dari dua kelas yang terpilih tersebut dilakukan pemilihan kembali 
secara acak untuk menentukan kelas perlakuan. Kelas VII 1 terpilih untuk diberi perlakuan dengan menerapkan pembelajaran dengan menggunakan pendekatan CTL setting NHT dan kelas VII 2 terpilih untuk diberi perlakuan dengan menerapkan pembelajaran dengan menggunakan pendekatan CTL setting TGT.

\section{Prosedur Penelitian}

Desain yang digunakan dalam penelitian ini adalah pretest-posttest non-equivalent comparison-group design. Adapun desain penelitian disajikan pada Gambar 1.

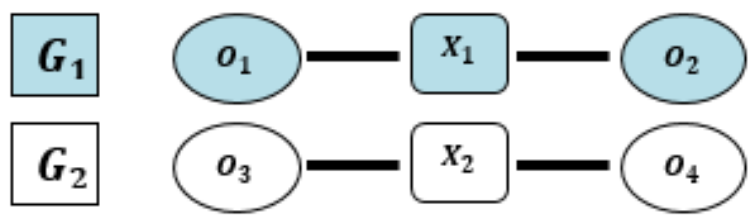

(Johnson \& Christensen, 2014, p. 329)

Gambar 1. Desain Penelitian

Keterangan:

$G_{1}$ : Kelompok Eksperimen Pertama

$G_{2}$ : Kelompok Eksperimen Kedua

$O_{1}$ : pretest kelompok eksperimen pertama

$\mathrm{O}_{2}$ : posttest kelompok eksperimen pertama

$\mathrm{O}_{3}$ : pretest kelompok eksperimen kedua

$\mathrm{O}_{4}$ : posttest kelompok eksperimen kedua

$X_{1}$ : Eksperimen Pertama

$X_{2}$ : Eksperimen Kedua

Langkah-langkah yang dilakukan dalam penelitian ini adalah sebagai berikut: memberikan pretest untuk mengetahui kondisi awal subjek; memberikan perlakuan pada kedua kelompok eksperimen dengan menerapkan pembel-ajaran menggunakan pendekatan CTL setting NHT dan TGT; memberikan posttest dalam waktu yang relatif bersamaan dan dengan bentuk soal yang setara pada kedua kelompok eksperimen; memberikan angket sikap pada kedua kelompok dan diisi dalam waktu yang relatif bersamaan; membandingkan keefektifan pembelajaran dengan menggunakan pendekatan CTL setting NHT dan TGT dilihat dari hasil pengukuran prestasi belajar, kemampuan komunikasi matematis, dan sikap matematika siswa.

\section{Teknik Pengumpulan Data}

Data penelitian ini dikumpulkan melalui tes dan nontes (angket) untuk kedua kelompok eksperimen. Tes digunakan untuk mengukur prestasi belajar dan kemampuan komunikasi matematis, sedangkan nontes (angket) digunakan untuk mengukur sikap matematika siswa. Adapun langkah-langkah yang digunakan untuk mengumpulkan data adalah sebagai berikut: menyusun instrumen penelitian; melakukan validasi instrumen oleh beberapa pakar; melakukan uji coba instrumen; memberikan pretest; menganalisis hasil pretest; melakukan tindakan penelitian; memberikan posttest; dan menganalisis data posttest.

\section{Teknik Analisis Data}

Teknik analisis data yang digunakan dalam penelitian ini adalah analisis deskriptif dan inferensial. Analisis deskriptif dilakukan untuk mendeskripsikan keadaan sebelum dan sesudah diberikan perlakuan pada kedua kelas eksperimen ditinjau dari masing-masing variabel terikatnya. Sedangkan analisis inferensial dilakukan untuk mengambil kesimpulan berdasarkan data yang telah diperoleh selama proses penelitian berlangsung. Analisis inferensial ini terdiri atas uji keefektifan dan uji komparasi pendekatan pembelajaran.

Keefektifan pendekatan pembelajaran ditentukan berdasarkan indeks keefektifan. Data tentang prestasi belajar diperoleh melalui tes berbentuk pilihan ganda, sedangkan data tentang kemampuan komunikasi matematis diperoleh melalui tes yang berbentuk uraian. Skor yang diperoleh dikonversi menjadi nilai dengan rentang antara 0 sampai 100. Skor tersebut kemudian digolongkan dalam kriteria ketuntasan minimal (KKM) yang ditetapkan oleh sekolah yaitu 80. Pembelajaran matematika yang ditinjau dari aspek prestasi dan kemampuan komunikasi dikatakan efektif jika rata-rata kelas melebihi 80.

Untuk data sikap matematika diperoleh dengan menggunakan instrumen nontes yang berbentuk checklist dengan skala Likert. Data yang diperoleh digolongkan dalam kriteria berdasarkan Tabel 3. Penyekoran angket sikap matematika dalam penelitian ini memiliki rentang antara 33 sampai 165. Untuk menentukan kriteria hasil pengukurannya digunakan klasifikasi berdasarkan rata-rata ideal (Mi) dan standar deviasi ideal $(\mathrm{Si})$. Dimana $\mathrm{Mi}=(33+$ 165) $/ 2=99$ dan $\mathrm{Si}=(165-33) / 6=22$.

Tabel 3. Kriteria Sikap Matematika Siswa

\begin{tabular}{cc}
\hline Skor $(\mathbf{X})$ & Kriteria \\
\hline $132<\mathrm{X} \leq 165$ & Sangat baik \\
$110<\mathrm{X} \leq 132$ & Baik \\
$88<\mathrm{X} \leq 110$ & Cukup baik \\
$66<\mathrm{X} \leq 88$ & Kurang baik \\
$33 \leq \mathrm{X} \leq 66$ & Sangat kurang baik \\
\hline
\end{tabular}

(Azwar, 2010, p. 163) 
Pembelajaran matematika yang ditinjau dari aspek sikap matematika dikatakan efektif jika minimal skor rata-rata yang dicapai adalah kategori baik atau mencapai nilai minimal 111.

Data-data yang diperoleh selama penelitian berlangsung, harus memenuhi uji asumsi terlebih dahulu sebelum melalui proses analisis. Uji asumsi yang harus dipenuhi adalah uji normalitas dan uji homogenitas. Uji normalitas dilakukan dengan menggunakan kriteria Chi square $X^{2}$ (Johnson \& Wichern, 2007, pp. 182183) yaitu nilai $d_{i}{ }^{2}<X^{2}{ }_{p}(0,5)$ mendekati $50 \%$ maka dapat dikatakan bahwa data tersebut berdistribusi normal multivariat. Sedangkan, homogenitas kedua kelompok di uji dengan menggunakan uji Box-M (Huberty, Olejnik, \& Huberty, 2006, p. 41). Jika nilai signifikansi yang diperoleh lebih dari 0,05 , maka matriks kovarians kedua populasi tersebut homogen.

Setelah melewati proses uji asumsi, maka dilanjut dengan uji one sample t-test untuk menganalisis keefektifan dari pendekatan CTL setting NHT dan TGT ditinjau dari masingmasing variabel terikatnya. Data yang dianalisis dengan uji one sample t-test adalah data posttest. Untuk pengujian secara manual, kriteria keputusannya adalah $H_{0}$ ditolak jika $t_{\text {hitung }}>t_{\text {tabel }}$, kriteria keputusannya adalah menolak $H_{0}$ jika $p$ value $<0,05$.

Setelah mengetahui keefektifan dari masing-masing pendekatan, langkah selanjutnya adalah menganalisis perbedaan keefektifan antara pendekatan CTL setting NHT dan pendekatan CTL setting TGT yaitu dengan uji Multivariate Analysis of Variance (MANOVA) $T^{2}$ Hotelling (Stevens, 2009, p. 148). Taraf signifikansi yang digunakan pada uji keefektifan adalah 0,05. Jika terdapat perbedaan keefektifan antara kedua pendekatan tersebut, maka dilakukan uji lanjut tunivariat untuk menentukan variabel-variabel tertentu yang berkontribusi terhadap perbedaan secara keseluruhan. Uji univariat dilakukan dengan menggunakan independent sample t-test. Kriteria keputusannya didasarkan pada kriteria Bonferroni dimana taraf signifikansinya adalah $\frac{\alpha}{p}$ dengan $\mathrm{p}=3$. Dengan demikian kriteria keputusannya adalah $H_{0}$ ditolak jika $t_{\text {hitung }}>$ $t_{\left(0,0167 ; n_{1}+n_{2}-2\right)}$.

\section{HASIL DAN PEMBAHASAN}

\section{Hasil}

Data yang diperoleh dalam penelitian ini adalah data prestasi belajar, data kemampuan komunikasi matematis, dan data angket sikap matematika siswa. Adapun data hasil penelitian tersaji pada beberapa tabel berikut.

Tabel 4. Data Prestasi Belajar Siswa

\begin{tabular}{ccccc}
\hline & \multicolumn{2}{c}{ CTL setting NHT } & \multicolumn{2}{c}{ CTL setting TGT } \\
\cline { 2 - 5 } & Pre & Post & Pre & Post \\
\hline $\bar{x}$ & 62,79 & 85,15 & 65,00 & 82,65 \\
SD & 11,16 & 10,26 & 17,32 & 11,36 \\
Max & 85 & 100 & 95 & 100 \\
Min & 45 & 45 & 15 & 55 \\
\hline
\end{tabular}

Keterangan:

$\bar{x}=$ rata-rata, $\mathrm{SD}=$ standar deviasi.

Berdasarkan hasil analisis data statistik deskriptif pada Tabel 4, rata-rata nilai prestasi belajar matematika siswa sebelum diberikan perlakuan (pretest) pada kelas CTL setting NHT adalah 62,79 dan pada kelas CTL setting TGT adalah 65,00. Hal ini menunjukkan bahwa nilai rata-rata pretest pada kedua kelas eksperimen relatif sama. Selain itu, tampak terdapat peningkatan skor rata-rata prestasi belajar sebelum dan sesudah perlakuan pada kedua kelompok eksperimen.

Tabel 5. Data Kemampuan Komunikasi Matematis Siswa

\begin{tabular}{ccccc}
\hline & \multicolumn{2}{c}{ CTL setting NHT } & \multicolumn{2}{c}{ CTL setting TGT } \\
\cline { 2 - 5 } & Pre & Post & Pre & Post \\
\hline $\bar{x}$ & 20,65 & 70,96 & 27,14 & 60,35 \\
SD & 10,71 & 15,08 & 20,57 & 24,47 \\
Max & 50 & 93,75 & 83,33 & 100 \\
Min & 2,08 & 29,17 & 0 & 16,67 \\
\hline \multicolumn{3}{c}{ Berdasarkan hasil analisis data } & statistik
\end{tabular}

deskriptif pada Tabel 5, tampak terdapat peningkatan kemampuan komunikasi matematis pada kedua kelompok. Pada kelompok CTL setting NHT skor kemampuan komunikasi matematis yang sebelum sebelumnya hanya 20,65 meningkat menjadi 70,96 dan pada kelompok CTL setting TGT sebelumnya hanya 27,14 meningkat menjadi 60,75 .

Tabel 6. Data Sikap Matematika Siswa

\begin{tabular}{ccccc}
\hline & \multicolumn{2}{c}{ CTL setting NHT } & \multicolumn{2}{c}{ CTL setting TGT } \\
\cline { 2 - 5 } & Pre & Post & Pre & Post \\
\hline $\bar{x}$ & 124,53 & 127,41 & 122,09 & 124,29 \\
SD & 10,15 & 11,79 & 11,16 & 15,27 \\
Max & 143 & 149 & 147 & 161 \\
Min & 98 & 93 & 92 & 90 \\
\hline
\end{tabular}

deskriptif pada Tabel 6, rata-rata skor angket sikap matematika siswa sebelum diberikan perlakuan pada kelas CTL setting NHT adalah 124,53 yaitu berada pada interval skor $110<\mathrm{X}$ $\leq 132$ (Baik) dan pada kelas CTL setting TGT 
adalah 122,09 yang juga berada pada interval skor $110<\mathrm{X} \leq 132$ (Baik). Rata-rata skor angket sikap matematika siswa setelah diberikan perlakuan pada kelas CTL setting NHT adalah 127,41 yaitu berada pada interval skor $110<\mathrm{X}$ $\leq 132$ (Baik) dan pada kelas CTL setting TGT adalah 124,294 yang juga berada pada interval skor $110<\mathrm{X} \leq 132$ (Baik). Tampak terlihat bahwa pada kedua kelas eksperimen terjadi peningkatan rata-rata skor sebelum dan setelah diberikan perlakuan.

Tabel 7. Distribusi Frekuensi Sikap Matematika

\begin{tabular}{cccccc}
\hline \multirow{2}{*}{ Kel } & \multirow{2}{*}{ Kat } & \multicolumn{2}{c}{ Pre } & \multicolumn{2}{c}{ Post } \\
\cline { 2 - 6 } & & $\mathbf{F}$ & $\boldsymbol{\%}$ & $\mathbf{F}$ & $\boldsymbol{\%}$ \\
\hline & SB & 7 & 20,59 & 11 & 32,35 \\
CTL setting NHT & B & 25 & 73,53 & 22 & 64,71 \\
& CB & 2 & 5,882 & 1 & 2,941 \\
& KB & 0 & 0 & 0 & 0 \\
& SKB & 0 & 0 & 0 & 0 \\
& SB & 4 & 12,12 & 10 & 29,41 \\
CTL setting TGT & B & 25 & 75,76 & 20 & 58,82 \\
& CB & 4 & 12,12 & 4 & 11,76 \\
& KB & 0 & 0 & 0 & 0 \\
& SKB & 0 & 0 & 0 & 0 \\
\hline
\end{tabular}

Keterangan:

$\mathrm{SB}=$ Sangat Baik, $\mathrm{B}=$ Baik, $\mathrm{CB}=$ Cukup Baik, KB $=$ Kurang Baik, $\mathrm{SKB}=$ Sangat Kurang Baik.

Berdasarkan Tabel 7, dapat diketahui bahwa pada kelompok CTL setting NHT setelah perlakuan, secara kumulatif $97,06 \%$ siswa memiliki kategori sikap matematika yang baik dan sangat baik, sedangkan sebelum perlakuan secara kumulatif $94,12 \%$, sehingga dapat dikatakan terdapat peningkatan sikap matematika siswa sebesar 2,94\%. Pada kelompok CTL setting TGT, sebesar $88,23 \%$ siswa memiliki kategori sikap matematika yang baik dan sangat baik, sedangkan sebelum perlakuan secara kumulatif $87,88 \%$, sehingga dapat dikatakan terdapat peningkatan sikap matematika siswa sebesar $0,35 \%$.

Data penelitian selanjutnya dianalisis untuk mengetahui keefektifan pendekatan pembelajaran pada masing-masing variabel terikat. Sebelum data dianalisis, terlebih dahulu data harus memenuhi uji asumsi. Hasil analisis pemenuhan asumsi normalitas dan homogenitas multivariat untuk data sebelum dan sesudah perlakuan tersaji pada Tabel 8 dan Tabel 9.

Tabel 8. Hasil Uji Normalitas Multivariat

\begin{tabular}{ccc}
\hline \multirow{2}{*}{ Kelas } & \multicolumn{2}{c}{$\boldsymbol{d}_{\boldsymbol{i}}{ }^{2}$} \\
\cline { 2 - 3 } & $\boldsymbol{P r e}$ & Post \\
\hline CTL setting NHT & $47,059 \%$ & $52,941 \%$ \\
CTL setting TGT & $54,545 \%$ & $50,000 \%$ \\
\hline
\end{tabular}

Tabel 9. Hasil Uji Homogenitas Multivariat

\begin{tabular}{ccc}
\hline & Pre & Post \\
\hline Box's $M$ & 25,936 & 12,383 \\
F & 4,106 & 1,962 \\
Sig & 0,000 & 0,067 \\
\hline
\end{tabular}

Hasil analisis menunjukkan bahwa semua data baik pretest maupun posttest pada kedua kelompok ksperimen, memiliki persentase jumlah $d_{i}{ }^{2}<X^{2}{ }_{p}(0,5)$ dipersekitaran $50 \%$. Hal tersebut menunjukan bahwa asumsi normalitas multivariat terpenuhi. Dari Tabel 9, terlihat bahwa nilai signifikansi yang diperoleh pada data pretest adalah 0,000 dimana $0,000<0,05$. Hal ini menunjukkan bahwa matriks varianskovarians untuk data pretest tidak homogen. Namun hal ini tidak menjadi masalah yang berarti, karena sampel penelitian dalam jumlah yang kecil dan $n_{1}=34>n_{2}=33$. Jika sampel dalam jumlah kecil dan matriks varianskovarians tidak homogen, maka hal ini hanya akan memberikan pengaruh yang kecil (Glass \& Hopkins, 1996, p. 238). Sedangkan untuk matriks varians-kovarians data posttest adalah homogen karena nilai signifikansi $=0,067$ lebih besar dari 0,05 .

Setelah uji asumsi terpenuhi, selanjutnya dilakukan uji MANOVA untuk mengetahui kesamaan vektor rerata pada masing-masing kelompok. Hasil uji MANOVA secara manual diperoleh nilai $F_{\text {hit }}=2,027$ dan $F_{\text {tabel }}=2,751$. Karena $F_{\text {hit }}<F_{\text {tabel }}$, maka hipotesis nol diterima. Artinya, tidak terdapat perbedaan ratarata skor pretest prestasi belajar, kemampuan komunikasi matematis, dan sikap matematika siswa pada kedua kelompok eksperimen. Hasil uji MANOVA dapat dilihat pada Tabel 10.

Tabel 10. Hasil Uji MANOVA Sebelum Perlakuan (Wilks' Lambda)

\begin{tabular}{cc}
\hline & Pre \\
\hline Value & 0,912 \\
F & 2,027 \\
Sig & 0,119 \\
\hline
\end{tabular}

Berdasarkan data, nilai signifikansi Wilks' Lambda lebih dari 0,05 (0,119>0,05). Hal ini menunjukkan bahwa kedua kelompok eksperimen memiliki rerata kelompok yang sama. Melihat kondisi awal kelompok, maka uji statistik yang akan digunakan untuk menganalisis perbedaan keefektifan antara kedua pendekatan adalah uji MANOVA (Multivariate Analysis of Variance).

Untuk mengetahui keefektifan dari pendekatan CTL setting NHT dan TGT ditinjau dari masing-masing variabel terikatnya, maka dilaku- 
kan uji one sample t-test. Adapun hasil uji one sample t-test ditunjukkan pada Tabel 11.

Tabel 11. Hasil Uji Keefektifan

\begin{tabular}{ccccc}
\hline Kel & Var & $\boldsymbol{t}_{\text {hit }}$ & $\boldsymbol{d} \boldsymbol{f}$ & Sig \\
\hline CTL & PB & 5,766 & 33 & 0,000 \\
setting & KMM & $-3,498$ & 33 & 0,999 \\
NHT & SM & 8,114 & 33 & 0,000 \\
CTL & PB & 3,924 & 33 & 0,000 \\
setting & KMM & $-4,696$ & 33 & 1,000 \\
TGT & SM & 5,076 & 33 & 0,000 \\
\hline
\end{tabular}

Berdasarkan hasil perhitungan pada Tabel 11, terlihat bahwa untuk variabel prestasi belajar (PB) dan sikap matematika (SM) pada kedua kelas eksperimen memiliki taraf signifikansi lebih kecil dari 0,05. Ini berarti pendekatan CTL setting NHT dan pendekatan CTL setting TGT efektif ditinjau dari aspek prestasi belajar dan sikap matematika. Namun untuk aspek kemampuan komunikasi matematis (KMM), kedua pendekatan tersebut tidak efektif karena nilai $\mathrm{t}_{\text {hitung }}$ adalah negatif dan taraf signifikansinya lebih dari 0,05 .

Setelah melakukan uji keefektifan, maka dilanjutkan dengan menguji perbedaan keefektifan antara pendekatan CTL setting NHT dengan pendekatan CTL setting TGT menggunakan uji multivariat $T^{2}$ Hotelling. Proses perhitungan dilakukan dengan dua cara yaitu secara manual dan dengan bantuan SPSS 21,0 for Windows. Dari hasil perhitungan secara manual diperoleh nilai $F_{\text {hitung }}=1,57$ dan $F_{\text {tabel }}$ $=2,75$, sedangkan hasil perhitungan dengan bantuan SPSS menunjukkan bahwa taraf signifikansi yang diperoleh sebesar 0,204. Karena $F_{\text {hitung }}<F_{\text {tabel }}$ dan taraf signifikansi $>0,05$, maka dapat disimpulkan bahwa tidak terdapat perbedaan keefektifan antara pembelajaran menggunakan pendekatan CTL setting NHT dan pembelajaran menggunakan pendekatan CTL setting TGT yang ditinjau dari prestasi belajar, kemampuan komunikasi matematis, dan sikap matematika siswa. Karena berdasarkan hasil perhitungan tersebut menyatakan tidak terdapat perbedaan keefektifan, maka tidak dapat dilakukan uji lanjut yaitu statistik uji t-univariat untuk melihat pembelajaran mana yang lebih efektif diantara kedua kelas eksperimen pada masing-masing variabel terikat.

\section{Pembahasan}

Untuk mengetahui tingkat keefektifan pendekatan CTL setting NHT dan TGT ditinjau dari aspek prestasi belajar dan kemampuan komunikasi matematis digunakan acuan kriteria ketuntasan minimal (KKM) yang ditetapkan oleh sekolah yakni sebesar 80. Pendekatan pembelajaran yang ditinjau dari aspek prestasi belajar dan kemampuan komunikasi matematis dikatakan efektif jika $75 \%$ siswa tuntas dalam belajar atau rata-rata klasikal posttest prestasi belajar dan kemampuan komunikasi matematis mencapai nilai KKM. Sedangkan untuk mengetahui tingkat keefektifan pendekatan CTL setting NHT dan pendekatan CTL setting TGT ditinjau dari aspek sikap matematika siswa didasarkan pada tabel kriteria sikap matematika. Pembelajaran memberikan pengaruh efektif terhadap aspek sikap matematika jika minimal skor rata-rata yang dicapai adalah kategori baik atau mencapai nilai minimal 111.

Berdasarkan hasil uji statistik one sample $t$-test, pembelajaran matematika dengan pendekatan CTL setting NHT efektif ditinjau dari aspek prestasi belajar dan sikap matematika siswa, namun tidak efektif ditinjau dari aspek kemampuan komunikasi matematis. Hal ini sesuai dengan hasil penelitian yang dilakukan oleh Zakaria, Chin, \& Daud (2010) bahwa pendekatan pembelajaran yang berpusat pada siswa seperti pembelajaran kooperatif efektif dalam meningkatkan prestasi belajar matematika dan sikap belajar siswa terhadap matematika. Hasil ini sesuai pula dengan hasil penelitian yang dilakukan oleh Amirin (2012) bahwa pendekatan CTL dikolaborasikan dengan model pembelajaran kooperatif tipe NHT efektif terhadap kemampuan pemecahan masalah. Padahal kemampuan pemecahan masalah termasuk prestasi belajar.

Pendekatan CTL setting NHT efektif ditinjau dari aspek prestasi belajar dan sikap matematika siswa karena materi bangun datar yang diajarkan dikaitkan dengan konteks kehidupan siswa sehari-hari, sehingga selama proses pembelajaran siswa dapat berpartisipasi aktif melalui kegiatan diskusi kelompok. Hal ini sesuai dengan penelitian yang dilakukan oleh (Berns \& Erickson, 2001) bahwa pendekatan kontekstual dapat memotivasi siswa dengan mengaitkan materi pelajaran dengan pengalaman nyata siswa. Dengan ini siswa akan lebih mudah memahami materi, menemukan banyak hal yang menarik dalam mempelajari matematika, dan mengaitkan materi yang diajarkan dengan kehidupan sehari-hari.

Pada setiap kelompok terlihat adanya proses berbagi pengetahuan dimana jika terdapat siswa yang belum memahami materi dan permasalahan dalam LKS. Adanya sistem 
penomoran dalam proses pembelajaran, sangat memotivasi para siswa untuk belajar lebih giat dan serius. Secara tidak langsung, metode pembelajaran seperti ini akan menambahkan sikap tanggung jawab individu setiap siswa terhadap kelompoknya.

Pada kelas yang berbeda, pembelajaran matematika dengan pendekatan CTL setting TGT juga efektif ditinjau dari aspek prestasi belajar dan sikap matematika siswa, namun tidak efektif ditinjau dari aspek kemampuan komunikasi matematis. Hal ini sesuai dengan hasil penelitian yang dilakukan oleh $\mathrm{Ke} \&$ Grabowski (2007) bahwa TGT efektif dalam meningkatkan prestasi akademik siswa dan sikap terhadap persoalan subjek. Hasil ini sesuai pula dengan hasil penelitian yang dilakukan oleh Muinah (2011) bahwa metode pembelajaran kooperatif tipe TGT efektif terhadap prestasi belajar dan minat belajar matematika siswa.

Pendekatan CTL setting TGT efektif ditinjau dari aspek prestasi belajar dan sikap matematika siswa disebabkan oleh beberapa hal, diantaranya karena siswa dituntut untuk berpartisipasi aktif selama proses pembelajaran di kelas. Setiap siswa harus mampu menguasai materi yang diajarkan, karena nantinya materi ini akan menjadi bekal mereka dalam mengikuti kegiatan permainan dan turnamen. Hasil tersebut selaras dengan hasil penelitian dari Trisnawati \& Wutsqa (2015, p. 305) yang menyatakan TGT efektif meningkatkan prestasi belajar. Menurut Borich (2007, p. 389) salah satu tujuan diberikan permainan dan turnamen adalah untuk memperlihatkan penguasaan materi yang telah siswa pelajari.

Pada prinsipnya jika semua siswa mampu menggabungkan kemampuannya dalam kelompok dengan baik, maka kelompok tersebut mempunyai peluang untuk menjadi kelompok dengan perolehan skor tertinggi. Semakin tinggi keinginan anggota kelompok untuk membuat kelompok mereka berhasil, semakin besar pula kemungkinan mereka untuk bekerja sama dan saling membantu satu sama lain. Adanya penghargaan yang diberikan guru kepada tiga kelompok terbaik juga sangat memotivasi para siswa untuk belajar matematika dengan baik dan serius. Jika para siswa ingin kelompoknya mendapat reward dari guru, maka mereka harus membantu teman satu timnya untuk bisa melakukan yang terbaik dan menunjukkan norma bahwa belajar itu penting dan menyenangkan.

Pendekatan CTL setting NHT dan TGT sama-sama tidak efektif ditinjau dari aspek kemampuan komunikasi matematis karena kemampuan siswa SMP Negeri 8 Yogyakarta kelas VII dalam menyelesaikan masalah dengan menggunakan langkah-langkah yang benar, urut, dan lengkap masih rendah. Mayoritas dari mereka belum dapat menyelesaikan soal-soal sesuai dengan langkah-langkah kemampuan komunikasi yang menuntut siswa untuk mengerjakan soal dengan langkah-langkah yang urut, lengkap, dan teliti. Sebagian besar siswa kurang teliti dalam memahami masalah, tidak memiliki pola dalam menuliskan penyelesaian, penyelesaiannya kurang sempurna, dan mereka tidak terbiasa menguji hasil yang telah diperoleh. Mereka selalu beranggapan bahwa ketika mereka mengerjakan soal yang terpenting adalah jawaban akhirnya bukan proses pengerjaannya.

Berdasarkan hasil analisis multivariat dengan MANOVA, diperoleh hasil bahwa hipotesis nol diterima. Ini artinya tidak terdapat perbedaan keefektifan antara pembelajaran menggunakan pendekatan CTL setting NHT dan TGT ditinjau dari prestasi belajar, kemampuan komunikasi matematis, dan sikap matematika siswa. Karena tidak terdapat perbedaan keefektifan diantara kedua pendekatan pembelajaran tersebut, maka tidak dapat dilakukan uji lanjut tunivariat guna menentukan variabel-variabel tertentu yang berkontribusi terhadap perbedaan secara keseluruhan.

Tidak terdapatnya perbedaan keefektifan diantara pendekatan CTL setting NHT dan TGT mungkin disebabkan oleh beberapa faktor. Salah satu faktornya adalah kegiatan turnamen yang merupakan sintaks dari pendekatan CTL setting TGT belum dilaksanakan secara optimal. Turnamen hanya dilaksanakan sebanyak tiga kali dari tujuh kali pertemuan yang ada. Kegiatan turnamen hanya dilakukan pada pertemuan yang jumlah jam pelajarannya $3 \times 40$ menit, karena untuk yang jam pelajaran $2 \times 40$ menit tidak cukup jika dilaksanakan kegiatan turnamen.

Faktor lain yang menyebabkan tidak terdapatnya perbedaan keefektifan diantara pendekatan CTL setting NHT dan pendekatan CTL setting TGT adalah faktor lingkungan. Setiap hari Senin pembelajaran matematika di kelas VII 1 yang menerapkan pendekatan CTL setting NHT diajarkan setelah jam pelajaran olahraga. Padahal jumlah jam pelajaran setiap hari Senin di kelas VII 1 adalah 3 jam pelajaran. Hal ini tentu sangat berpengaruh terhadap kegiatan belajar mengajar di kelas. Kegiatan pembelajaran pasti berkurang waktunya karena para siswa meminta tambahan waktu untuk berganti 
pakaian dan istirahat. Terlebih lagi konsentrasi mereka untuk belajar juga akan terganggu.

Secara umum, dari uraian di atas dapat dikatakan bahwa pembelajaran menggunakan pendekatan CTL setting NHT dan pembelajaran menggunakan pendekatan CTL setting TGT mempunyai tingkat keefektifan yang sama atau setara jika ditinjau dari aspek prestasi belajar, kemampuan komunikasi matematis, dan sikap matematika siswa.

\section{SIMPULAN}

Berdasarkan hasil analisis data dan pembahasan, maka dapat disimpulkan beberapa hal sebagai berikut: pembelajaran matematika dengan pendekatan CTL setting NHT dan TGT efektif ditinjau dari aspek prestasi belajar dan sikap matematika siswa SMP kelas VII dalam materi bangun datar, namun tidak efektif ditinjau dari aspek kemampuan komunikasi matematis; tidak terdapat perbedaan keefektifan antara pembelajaran matematika dengan pendekatan CTL setting NHT dan pembelajaran matematika dengan pendekatan CTL setting TGT ditinjau dari aspek prestasi belajar, kemampuan komunikasi matematis, dan sikap matematika siswa SMP kelas VII dalam materi bangun datar.

\section{DAFTAR PUSTAKA}

Amirin, I. (2012). Efektivitas pembelajaran matematika denganpendekatan contextual teaching and learning (CTL) dikolaborasikan dengan pembelajaran kooperatif tipenumbered head together (NHT) terhadap kemampuan pemecahan masalah dan keaktifan siswa kelas VIII SMP negeri. UIN Sunan Kalijaga Yogyakarta. Retrieved from http://digilib.uin-suka.ac.id/10867/

Azwar, S. (2010). Tes prestasi: Fungsi dan pengembangan pengukuran prestasi belajar. Yogyakarta: Pustaka Belajar. http://doi.org/1998

Berns, R. G., \& Erickson, P. M. (2001). Contextual teaching and learning: preparing students for the new economy. The Highlight Zone: Research (c) Work, (5), 1-9. Retrieved from http://files.eric.ed.gov/fulltext/ED452376. pdf

Borich, G. D. (2007). Effective teaching methods : research-based practice. Upper Saddle River: Pearson Publication.
Depdiknas. (2011). Laporan hasil dan statistik nilai ujian nasional tahun pelajaran 2010/2011. Jakarta.

Depdiknas. (2012). Laporan hasil dan statistik nilai ujian nasional tahun pelajaran 2011/2012. Jakarta.

Depdiknas. (2013). Laporan hasil dan statistik nilai ujian nasional tahun pelajaran 2012/2013. Jakarta.

Glass, G. V, \& Hopkins, K. D. (1996). Statistical methods in education and psychology. New Jersey: Allyn and Bacon.

Hirschfeld-Cotton, K. (2008). Mathematical communication, conceptual understanding, and students' attitudes toward mathematics. Nebraska. Retrieved from

http://digitalcommons.unl.edu/cgi/viewco ntent.cgi? article $=1011 \&$ context $=$ mathmid actionresearch

Huberty, C. J., Olejnik, S., \& Huberty, C. J. (2006). Applied MANOVA and discriminant analysis. New Jersey: Wiley-Interscience.

Johnson, B., \& Christensen, L. B. (2014). Educational research: Quantitative, qualitative, and mixed approaches. London: SAGE Publications.

Johnson, R. A., \& Wichern, D. W. (2007). Applied multivariate statistical analysis. New Jersey: Prentice Hall.

Ke, F., \& Grabowski, B. (2007). Gameplaying for maths learning: cooperative or not? British Journal of Educational Technology Gameplaying for Maths LearningBritish Journal of Educational Technology, 38(2). http://doi.org/10.1111/j.14678535.2006.00593.x

Kose, S., Sahin, A., Ergun, A., \& Gezer, K. (2010). The effects of cooperative learning experience on eight grade students achievement and attitude toward science. Education, 131(1), 169-180.

Marsigit. (2013a). Metode Pembelajaran yang cocok untuk Kurikulum 2013. Jakarta . Retrieved from https://www.academia.edu/3854314/Meto de_Pembelajaran_yang_cocok_untuk_Ku rikulum_2013

Marsigit. (2013b). Tantangan dan harapan 
Kurikulum 2013. In Seminar Nasional Matematika dan Pendidikan Matematika. Yogyakarta: Universitas PGRI Yogyakarta. Retrieved from https://www.academia.edu/3727714/Tanta ngan_dan_Harapan_Kurikulum_2013

Menteri Pendidikan dan Kebudayaan Republik Indonesia. Peraturan menteri pendidikan dan kebudayaan No.58 tentang kurikulum 2013 sekolah menengah pertama/madrasah tsanawiyah, Undangundang (2014).

Muinah, M. (2011). Perbandingan keefektifan pembelajaran kooperatif tipe team game tournament (TGT) dan numbered head together (NHT) pada prestasi belajar dan minat belajar matematika siswa kelas VII SMP Negeri 3 Gantiwarno. Universitas Negeri Yogyakarta. Retrieved from http://eprints.uny.ac.id/40255/

OECD. (2010). PISA 2009 results: What students know and can do: Student performance in reading, mathematics and science (volume I). Retrieved from https://www.oecd.org/pisa/pisaproducts/4 8852548.pdf

Slavin, R. E. (2005). Cooperative learning: Theory, research, and practice. London: Allyn and Bacon.

Slavin, R. E. (2014). Educational Psychology Theory and Practice- Pearson Etext Access Card. Pearson College Div.

Stevens, J. P. (2009). Applied multivariate statistics for the social sciences. London: Routledge.

The National Council of Teachers of Mathematics. (2000). NCTM principles and standards for school mathematics,. Association Drive, Reston, VA: Library of Congres Cataloguing-in-Publication Data. Retrieved from https://www.nctm.org/store/Products/NC TM-Principles-and-Standards-for-SchoolMathematics,-Full-Edition-(PDF)/

Trisnawati, T., \& Wutsqa, D. U. (2015). Perbandingan keefektifan quantum teaching dan TGT pada pembelajaran matematika ditinjau dari prestasi dan motivasi. Jurnal Riset Pendidikan Matematika, 2(2), 296. http://doi.org/10.21831/jrpm.v2i2.7348

Widdiharto, R. (2004). Model-model pembelajaran matematika SMP. Yogyakarta: Departemen Pendidikan Nasional, Direktorat Jendral Pendidikan Dasar dan Menengah, Pusat Pengembangan Penataran Guru (PPG) Matematika.

Zakaria, E., Chin, L. C., \& Daud, M. Y. (2010). The effects of cooperative learning on students' mathematics achievement and attitude towards mathematics. Journal of Social Sciences, 6(2), 272-275. Retrieved from

http://thescipub.com/PDF/jssp.2010.272.2 75.pdf 